With compliments of the Author 


\title{
On-Water Synthesis of Dipyrromethanes via Bis-Hetero-Diels-Alder Reaction of Azo- and Nitrosoalkenes with Pyrrole
}

\author{
Nelson A. M. Pereira, ${ }^{a}$ Susana M. M. Lopes, ${ }^{a}$ Américo Lemos, ${ }^{\text {b }}$ Teresa M. V. D. Pinho e Melo*a \\ a Department of Chemistry, University of Coimbra, 3004-535 Coimbra, Portugal \\ E-mail: tmelo@ci.uc.pt \\ b CIQA, FCT, University of Algarve, Campus de Gambelas, 8005-139 Faro, Portugal \\ Received: 17.09.2013; Accepted after revision: 28.10.2013
}

\begin{abstract}
An unprecedented one-pot approach to 5-substituted dipyrromethanes based on the hetero-Diels-Alder reaction of azoand nitrosoalkenes is described. The on-water reaction conditions led to the target compounds in higher yields with significantly shorter reaction times and simpler purification procedures than carrying out the reaction in dichloromethane or in the absence of solvent.
\end{abstract}

Key words: dipyrromethane, Diels-Alder reactions, on-water reactions, azoalkenes, nitrosoalkenes

Dipyrromethanes are of wide interest as building blocks in organic synthesis, namely in the synthesis of porphyrins and porphyrin analogues such as meso-substituted corroles, chlorins, expanded porphyrins, and calix[4]pyrroles. ${ }^{1}$ These porphyrin-type macrocycles have remarkable photo- and biochemical properties. They have a rich pattern of absorption bands particularly in the red and near-infrared region of the spectra which makes them ideal to be used in light-energy conversion processes such as in the mimicking of photosynthetic processes ${ }^{2}$ or in electric energy production by dye-sensitized solar cells. ${ }^{3}$ In medicine, the most relevant applications of porphyrin derivatives are in medical imaging and in photodynamic therapy ${ }^{4}$ More recently, there has been a growing interest in various other applications of dipyrromethanes. In fact, dipyrromethanes are the precursors of BODIPY dyes $(4,4-$ difluoro-4-bora-3a,4a-diaza-s-indacenes) whose photophysical properties make them the ideal fluorescent scaffold for the development of high-performance imaging probes, also finding application as photonic organic-based materials. ${ }^{5}$ Functionalized dipyrromethanes are also potentially attractive structures for the development of new optical anion sensors, for application in biological systems and in the settling of environmental problems. ${ }^{6}$

Dipyrromethanes can be obtained from the acid-catalyzed condensation of aldehydes (or ketones) with pyrrole. The drawbacks of this approach are the competitive formation of tripyrromethanes and higher oligopyrromethanes, as well as N-confused dipyrromethane derivatives. Therefore, over the years, significant efforts have been made to overcome this problem. ${ }^{1}$ Alternative approaches to dipyrromethanes include the condensation of pyrrole carbinol

SYNLETT 2014, 25, 0423-0427

Advanced online publication: 04.12.2013

DOI: 10.1055/s-0033-1340300; Art ID: ST-2013-D0887-L

(C) Georg Thieme Verlag Stuttgart · New York derivatives with pyrroles ${ }^{1,7}$ and the acid-catalyzed condensation of $\alpha$-acetoxymethylpyrroles with other pyrrole derivatives or self-condensation. ${ }^{8}$ Dipyrromethanes bearing a hydroxyalkyl or aminoalkyl substituent at C-5 have also been prepared by the reaction of pyrrole with cyclic vinyl ethers and cyclic enecarbamates, respectively, in the presence of indium bromide. ${ }^{9}$ A two-step approach to dipyrromethanes based on the Michael addition of pyrrole to 2-alkenylpyrroles is also known. ${ }^{10}$ On the other hand, pyrrole adds to alkynes to give dipyrromethanes, using a catalytic amount of $\operatorname{In}(\mathrm{OTf})_{3}$ or dinuclear ruthenium complexes. ${ }^{11,12}$ 5-(Trifluoromethyl)dipyrromethanes have been prepared starting from 1-bromo-1-chloro-2,2,2-trifluoroethane and pyrrole or $N$-methylpyrrole in the presence of sodium dithionite acting as free-radical initiator. ${ }^{13}$ Despite the available synthetic methodologies there is still demand for wider structural diversity due to the large range of applications of dipyrromethanes.

Over the past decades the impressive role of conjugated nitroso- and azoalkenes in the preparation of new heterocyclic systems, used either as Michael-type acceptors in conjugate 1,4-additions or in cycloaddition reactions, has been consolidated. ${ }^{14}$ Our own contribution included the functionalization of dipyrromethanes by the Diels-Alder reaction with these heterodienes. ${ }^{15}$ In fact, 5,5'-diethyland 5-phenyldipyrromethanes participated in cycloadditions with azo- and nitrosoalkenes giving dipyrromethanes with side chains containing open-chain oximes and hydrazones. Controlling reaction stoichiometry it is possible to obtain mono- or 1,9-disubstituted derivatives.

Despite their widespread use as synthetic intermediates, the vast majority of the known reports explore the reactivity of nitroso- and azoalkenes having C-bonded groups at the 4-position or 4-unsubstituted derivatives. The presence of a good leaving group at this position, namely a chlorine or bromine atom, provides an extra functionality to be explored in a subsequent functionalization of adducts and cycloadducts.

Nevertheless, 4-halo-nitrosoalkenes have been used in cycloadditions with electron-rich alkenes, but surprisingly the literature reports are scarce. ${ }^{16}$ There are also only a few reports on the chemistry of 4-haloazoalkenes and 4,4-dihaloazoalkenes. ${ }^{17}$ We envisaged that the base-mediated dehydrohalogenation of $\alpha, \alpha$-dihalohydrazones or $\alpha, \alpha$-dihalooximes in the presence of pyrrole would lead to 
two consecutive Diels-Alder reactions giving dipyrromethanes in a one-pot procedure (Scheme 1).

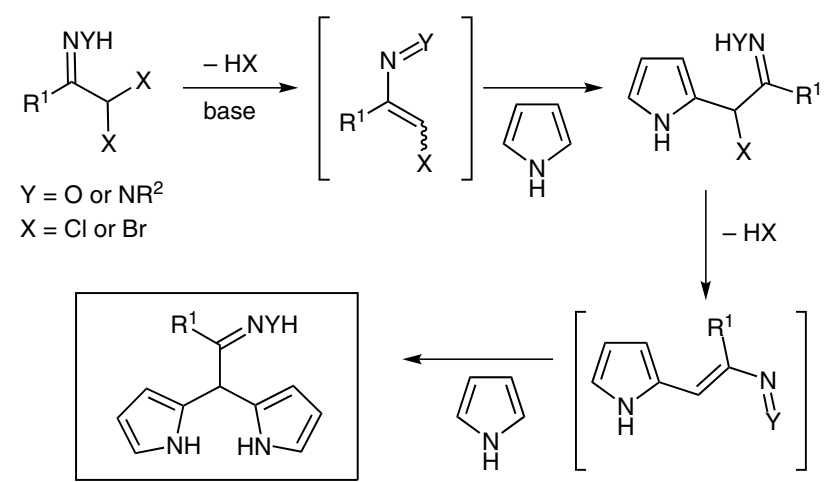

Scheme 1 Synthetic strategy for the synthesis of dipyrromethanes

In this communication, this novel approach to 5-substituted dipyrromethanes is described.

Initially, the reactivity of pyrrole towards $\alpha, \alpha$-dichlorohydrazone 1a was explored (Table 1). Usually, the transient azoalkenes are slowly generated at room temperature from the corresponding $\alpha$-halohydrazones by the action of sodium carbonate whose low solubility in dichloromethane ensures a slow rate of dehydrohalogenation and consequently a low concentration of the heterodiene thus preventing or diminishing dimerization reactions. Therefore, the reaction of $\alpha, \alpha$-dichlorohydrazone $\mathbf{1 a}$ with pyrrole ( 9 equiv) was carried out under these reaction conditions with a reaction time of 24 hours which gave the target compound 2a in low yield (Table 1, entry 1). Using a larger excess of pyrrole and longer reaction time, a slight improvement of the yield was observed (Table 1, entry 2 ). Then, the reaction of hydrazone 1a was carried out with excess of pyrrole (87 equiv) without solvent, a strategy used in the synthesis of dipyrromethanes via acid-catalyzed condensation of aldehydes and pyrroles to avoid the formation of oligopyrromethanes. ${ }^{18}$ Under these reaction conditions, dipyrromethane $\mathbf{2 a}$ could be obtained after 24 hours in moderate isolated yield (Table 1 , entry 3 ). The unreacted pyrrole was recovered by distillation followed by purification of the product by flash chromatography. Interestingly, increasing the reaction time to 66 hours the expected 5-substituted dipyrromethane $\mathbf{2 a}$ was isolated in $75 \%$ yield (Table 1, entry 4 ). These optimized reaction conditions were also applied to the synthesis of dipyrromethane $\mathbf{2 b}$ from $\alpha, \alpha$-dichlorohydrazone $\mathbf{1 b}$ and pyrrole (Table 1, entry 5). However, the target dipyrromethane $\mathbf{2 b}$ was obtained in low yield (17\%), and an azoalkene selfcondensation product was also isolated. In fact, treatment of $\alpha, \alpha$-dichlorohydrazone $\mathbf{1 b}$ with sodium carbonate at room temperature led to the synthesis of the same product which was identified as being 1,4-dihydro-1,2,3,4-tetrazine 3 (Scheme 2, see Supporting Information). Finally, the synthesis of dipyrromethane $2 \mathbf{c}$ was also achieved in a
Table 1 Synthesis of Dipyrromethanes from $\alpha, \alpha$-Dichlorohydrazones and Pyrrole

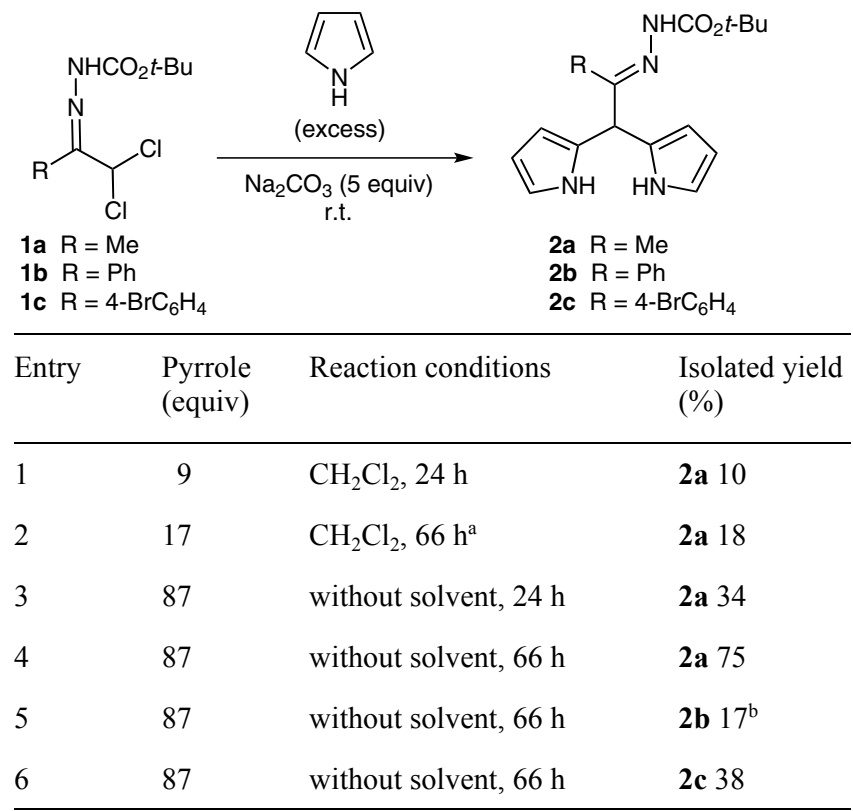

a Conditions: 10 equiv of $\mathrm{Na}_{2} \mathrm{CO}_{3}$ were used.

${ }^{\mathrm{b}}$ Azoalkene self-condensation product $\mathbf{3}$ was also isolated.<smiles>CC(C)(C)NC(=O)NN=C(c1ccccc1)C(Cl)C(C)(C)C</smiles><smiles>CC(C)(C)OC(=O)n1[nH]cc(-c2ccccc2)[nH]n1C(=O)OC(C)(C)C</smiles>

Scheme 2 Self-condensation of hydrazone $\mathbf{1 b}$

moderate $38 \%$ yield by reacting pyrrole with $\alpha, \alpha$-dichlorohydrazone 1c (Table 1, entry 6).

The study was extended to the Diels-Alder reaction of pyrrole with nitrosoalkenes generated from $\alpha, \alpha$-dihalooximes (Scheme 3). Starting from $\alpha, \alpha$-dichlorooxime 4a under the optimized reaction conditions, dipyrromethane $\mathbf{5 a}$ could be obtained in only $25 \%$ yield. From the reaction of $\alpha, \alpha$-dichlorooxime $\mathbf{4 b}$ with pyrrole the two isomeric oximes $6 \mathbf{a}$ and $\mathbf{6 b}$ were obtained in $17 \%$ overall yield. The assignment of the structure of compounds $6 \mathbf{a}$ and $\mathbf{6 b}$ was supported by two-dimensional NOESY spectra (400 $\mathrm{MHz}$ ). Connectivity was observed between the $\mathrm{OH}$ proton and protons of the phenyl group in the NOESY spectrum of compound $\mathbf{6 a}$, whereas no such correlation was detected in the case of oxime $\mathbf{6 b}$. On the other hand, in the ${ }^{1} \mathrm{H}$ NMR spectrum of dipyrromethane $\mathbf{6 b}$ the meso proton is identified at higher chemical shift than the value observed for derivative $\mathbf{6 a}$. The same features are seen in the ${ }^{1} \mathrm{H}$ NMR spectra of the isomeric oximes $\mathbf{4 b} .{ }^{19}$ These observations allowed us to assign the stereochemistry of other dipyrromethanes bearing the oxime substituent. Dehydrobromination of $\alpha, \alpha$-dibromooxime $4 \mathbf{c}$ in the presence of pyrrole led to dipyrromethane $7 \mathbf{a}$ in low yield (11\%). 


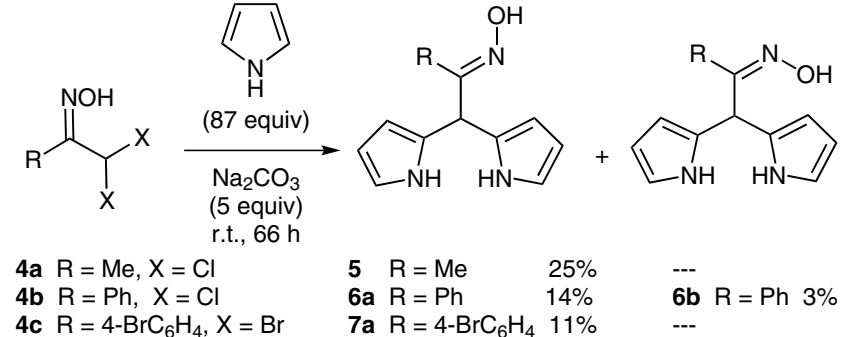

Scheme 3 Synthesis of dipyrromethanes from $\alpha, \alpha$-dihalooximes and pyrrole

The above results show that dipyrromethanes can be prepared from dehydrohalogenation of $\alpha, \alpha$-dichlorohydrazones or $\alpha, \alpha$-dihalooximes in the presence of pyrrole. However, the target compounds were obtained in moderate to low yields, which led us to explore other reaction conditions. Recently, on-water reactions have generated much interest. ${ }^{20}$ Water is a desirable solvent, not only because it is inexpensive and environmentally benign, but also because it can give completely new reactivity. On the other hand, Diels-Alder reactions can be greatly accelerated and can lead to higher selectivity and higher yield by using water as solvent instead of organic solvents. Attanasi et al. have demonstrated that Diels-Alder reactions of azoalkenes with electron-rich dienophiles were faster and gave higher yields in the heterogeneous aqueous medium in comparison to the homogeneous organic solvents. ${ }^{21}$ Thus, the on-water reactivity of $\alpha, \alpha$-dichlorohydrazones 1 and $\alpha, \alpha$-dihalooximes 4 towards pyrrole was explored (Table 2 and Scheme 4).

The optimized conditions for the synthesis of dipyrromethanes $\mathbf{2}$ bearing hydrazone substituents proved to be the use of 20 equivalents of pyrrole, carrying out the reaction at room temperature for four hours. From the reaction of hydrazones 1a and 1c the target dipyrromethanes $\mathbf{2 a}$ and $2 \mathbf{c}$ could be isolated in $82 \%$ and $79 \%$ yield, respectively (Table 2 , entries 4 and 8 ). It is noteworthy that the on-water reactions allow the synthesis of the dipyrromethanes in significantly shorter reaction times and lower pyrrole excess, leading to higher yields than the solvent-free conditions. Furthermore, the products could be purified by crystallization. The reaction of $\alpha, \alpha$-dichlorohydrazone 1b with pyrrole was less efficient due to the competitive formation of the self-condensation product 3 (Table 2, entries 5 and 6).

The optimized on-water conditions were also applied to the synthesis of dipyrromethanes 5-7 from $\alpha, \alpha$-dihalooximes 4 and pyrrole (Scheme 4). Starting from oxime 4a the corresponding dipyrromethane 5a was isolated in 74\% yield. The reaction of $\alpha, \alpha$-dihalooximes $\mathbf{4 b}$ and $\mathbf{4 c}$ afforded mixtures of isomers in $57 \%$ and $76 \%$ overall yield, respectively. The two isomers could be separated by flash chromatography.

In conclusion, the base-mediated dehydrohalogenation of $\alpha, \alpha$-dihalohydrazones and $\alpha, \alpha$-dihalooximes in the pres-
Table 2 On-Water Synthesis of Dipyrromethanes from $\alpha, \alpha$-Dichlorohydrazones and Pyrrole ${ }^{22}$

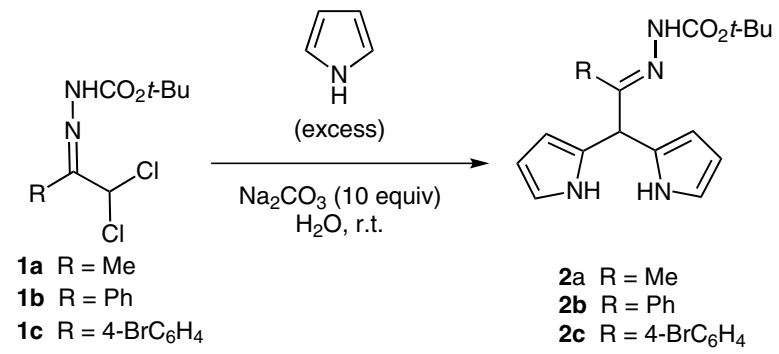

\begin{tabular}{llll}
\hline Entry & Pyrrole (equiv) & Time (h) & Isolated yield (\%) \\
\hline 1 & 10 & 2 & $\mathbf{2 a ~} 16^{\mathrm{a}}$ \\
2 & 20 & 0.75 & $\mathbf{2 a ~} 25^{\mathrm{a}}$ \\
3 & 20 & 4 & $\mathbf{2 a} 46^{\mathrm{a}}$ \\
4 & 20 & 4 & $\mathbf{2 a} 82^{\mathrm{b}}$ \\
5 & 20 & 4 & $\mathbf{2 b} 21^{\mathrm{a}, \mathrm{c}}$ \\
6 & 20 & 4 & $\mathbf{2 b} 21^{\mathrm{b}, \mathrm{c}}$ \\
7 & 20 & 4 & $\mathbf{2 c} 54^{\mathrm{a}}$ \\
8 & 20 & 4 & $\mathbf{2 c} 79^{\mathrm{b}}$ \\
\hline
\end{tabular}

${ }^{\text {a }}$ Purified by flash chromatography.

${ }^{\mathrm{b}}$ Purified by crystallization.

${ }^{\mathrm{c}}$ Azoalkene self-condensation product $\mathbf{3}$ was also isolated.

ence of pyrrole led to two consecutive Diels-Alder reactions affording 5-substituted dipyrromethanes in a novel one-pot procedure. These hetero-Diels-Alder reactions are accelerated and give higher yields using water as solvent allowing simpler purification procedures than carrying out the reaction in dichloromethane or in the absence of solvent.

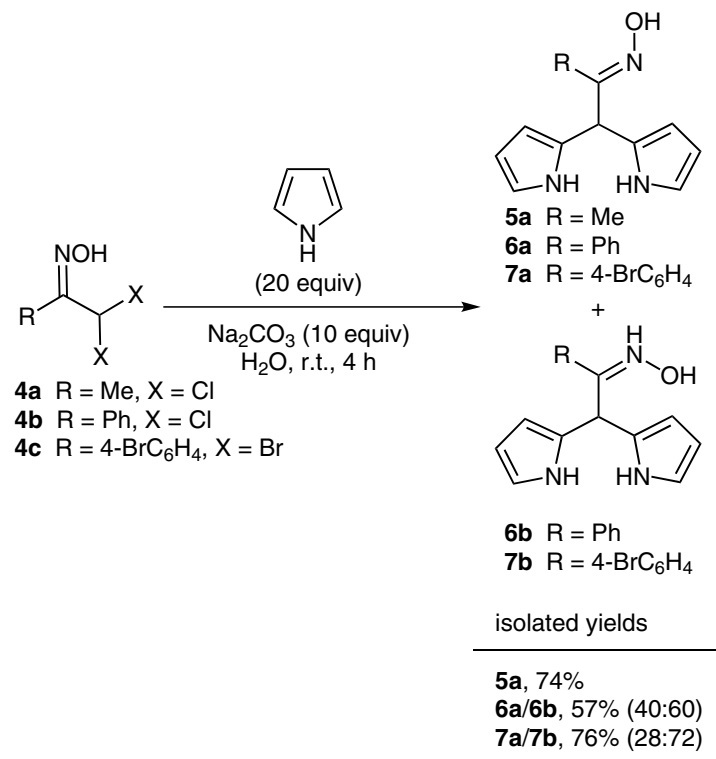

Scheme 4 On-water synthesis of dipyrromethanes from $\alpha, \alpha$-dihalooximes and pyrrole ${ }^{22}$ 


\section{Acknowledgment}

Thanks are due to Fundação para a Ciência e a Tecnologia (PEst-C/QUI/UI0313/2011, SFRH/BPD/84413/2012 and SFRH/BD/61573/2009) for financial support. We acknowledge the Nuclear Magnetic Resonance Laboratory of the Coimbra Chemistry Center (www.nmrccc.uc.pt), University of Coimbra for obtaining the NMR data.

Supporting Information for this article is available online at http://www.thieme-connect.com/ejournals/toc/synlett.

\section{References and Notes}

(1) (a) Gryko, D. T.; Gryko, D.; Lee, C.-H. Chem. Soc. Rev. 2012, 41, 3780. (b) Lindsey, J. S. Acc. Chem. Res. 2010, 43, 300. (c) Wood, T. E.; Thompson, A. Chem. Rev. 2007, 107, 1831. (d) Gale, P. A.; Anzenbacher, P. Jr.; Sessler, J. L. Coord. Chem. Rev. 2001, 222, 57. (e) Yedukondalu, M.; Ravikanth, M. Coord. Chem. Rev. 2011, 255, 547. (f) Pareek, Y.; Ravikanth, M.; Chandrashekar, T. K. Acc. Chem. Res. 2012, 45, 1801. (g) Roznyatovskiy, V. V.; Lee, C.-H.; Sessler, J. L. Chem. Soc. Rev. 2013, 42, 1921.

(2) (a) Wasielewski, M. R. Acc. Chem. Res. 2009, 42, 1910. (b) Leslie, M. Science 2009, 323, 1286. (c) Balzani, V.; Credi, A.; Venturi, M. ChemSusChem 2008, 1, 26.

(3) (a) Wang, X.-F.; Tamiaki, H. Energy Environ. Sci. 2010, 3, 94. (b) Stromberg, J. R.; Marton, A.; Kee, H. L.; Kirmaier, C.; Diers, J. R.; Muthiah, C.; Taniguchi, M.; Lindsey, J. S.; Bocian, D. F.; Meyer, G. J.; Holten, D. J. Phys. Chem. C 2007, 111, 15464. (c) Hasselman, G. M.; Watson, D. F.; Stromberg, J. R.; Bocian, D. F.; Holten, D.; Lindsey, J. S.; Meyer, G. J. J. Phys. Chem. B 2006, 110, 25430. (d) Li, L.-L.; Diau, E. W.-G. Chem. Soc. Rev. 2013, 42, 291.

(4) (a) Lovell, J.; Liu, T. W. B.; Chen, J.; Zheng, G. Chem. Rev. 2010, 110, 2839. (b) Juzeniene, A.; Peng, Q.; Moan, J. Photochem. Photobiol. Sci. 2007, 6, 1234. (c) Licha, K. Top. Curr. Chem. 2002, 222, 1. (d) Plaetzer, K.; Krammer, B.; Berlanda, J.; Berr, F.; Kiesslich, T. Lasers Med. Sci. 2009, 24, 259.

(5) (a) Boens, N.; Leen, V.; Dehaen, W. Chem. Soc. Rev. 2012, 41, 1130. (b) Benstead, M.; Mehl, G. H.; Boyle, R. W. Tetrahedron 2011, 67, 3573. (c) Suzuki, S.; Kozaki, M.; Nozaki, K.; Okada, K. J. Photochem. Photobiol., C 2011, 12, 269. (d) Brothers, P. J. Inorg. Chem. 2011, 50, 12374. (e) Yang, Y.; Zhao, Q.; Feng, W.; Li, F. Chem. Rev. 2012, 113, 192. (f) Wysocki, L. M.; Lavis, L. D. Curr. Opin. Chem. Biol. 2011, 15, 752. (g) Wang, S.; Li, N.; Pan, W.; Tang, B. Trend. Anal. Chem. 2012, 39, 3. (h) Dean, K. M.; Qin, Y.; Palmer, A. E. Biochim. Biophys. Acta, Mol. Cell Res. 2012, 1823, 1406. (i) Luo, S.; Zhang, E.; Su, Y.; Cheng, T.; Shi, C. Biomaterials 2011, 32, 7127. (j) Vigato, P. A.; Peruzzo, V.; Tamburini, S. Coord. Chem. Rev. 2012, 256, 953.

(6) (a) Beer, P. D.; Gale, P. A. Angew. Chem. Int. Ed. 2001, 40, 486. (b) Caltagirone, C.; Gale, P. A. Chem. Soc. Rev. 2009, 38, 520. (c) Wenzel, M.; Hiscock, J. R.; Gale, P. A. Chem. Soc. Rev. 2012, 41, 480.

(7) (a) Sreedevi, K. C. G.; Thomas, A. P.; Salini, P. S.; Ramakrishnan, S.; Anju, K. S.; Holaday, M. G. D.; Reddy, M. L. P.; Suresh, C. H.; Srinivasan, A. Tetrahedron Lett. 2011, 52, 5995. (b) Sobenina, L. N.; Vasil'tsov, A. M.; Petrova, O. V.; Petrushenko, K. B.; Ushakov, I. A.; Clavier, G.; Meallet-Renault, R.; Mikhaleva, A. I.; Trofimov, B. A. Org. Lett. 2011, 13, 2524. (c) Sobenina, L. N.; Petrova, O.
V.; Petrushenko, K. B.; Ushakov, I. A.; Mikhaleva, A. I.; Meallet-Renault, R.; Trofimov, B. A. Eur. J. Org. Chem. 2013, 4107.

(8) (a) Mikhalitsyna, E. A.; Tyurin, V. S.; Nefedov, S. E.; Syrbu, S. A.; Semeikin, A. S.; Koifman, O. I.; Beletskaya, I. P. Eur. J. Inorg. Chem. 2012, 5979. (b) Nakamura, M.; Tahara, H.; Takahashi, K.; Nagata, T.; Uoyama, H.; Kuzuhara, D.; Mori, S.; Okujima, T.; Yamada, H.; Uno, H. Org. Biomol. Chem. 2012, 6840.

(9) Yadav, J. S.; Subba Reddy, B. V.; Sunder Ram Reddy, P.; Reddy, K. S.; Reddy, P. N. Synlett 2003, 417.

(10) Hong, S.-J.; Lee, M.-H.; Lee, C.-H. Bull. Korean Chem. Soc. 2004, 25, 1545.

(11) Tsuchimoto, T.; Hatanaka, K.; Shirakawa, E.; Kawakami, Y. Chem. Commun. 2003, 2454.

(12) Tan, S. T.; Teo, Y. C.; Fan, W. Y. J. Organomet. Chem. 2012, 708-709, 58.

(13) Dmowski, W.; Piasecks-Maciejewska, K.; UrbańczykLipkowska, Z. Synthesis 2003, 841.

(14) Reviews: (a) Sukhorukov, A. Y.; Ioffe, S. L. Chem. Rev. 2011, 111, 5004. (b) Attanasi, O. A.; De Crescentini, L.; Favi, G.; Filippone, P.; Mantellini, F.; Perrulli, F. R.; Santeusanio, S. Eur. J. Org. Chem. 2009, 3109.

(15) Pereira, N. A. M.; Lemos, A.; Serra, A. C.; Pinho e Melo, T. M. V. D. Tetrahedron Lett. 2013, 54, 1553.

(16) (a) Zhang, Y.; Stephens, D.; Hernandez, G.; Mendoza, R.; Larionov, O. V. Chem. Eur. J. 2012, 18, 16612. (b) Yoon, S. C.; Kim, K.; Park, Y. J. J. Org. Chem. 2001, 66, 7337. (c) Zimmer, R.; Angermann, J.; Hain, U.; Hiller, F.; Reissig, H.-U. Synthesis 1997, 1467.

(17) (a) Lemos, A.; Lourenço, J. P. ARKIVOC 2010, (v), 170. (b) South, M. S. J. Heterocycl. Chem. 1999, 36, 301. (c) South, M. S.; Jakuboski, T. L.; Westmeyer, M. D.; Dukesherer, D. R. J. Org. Chem. 1996, 61, 8921. (d) South, M. S.; Jakuboski, T. L.; Westmeyer, M. D.; Dukesherer, D. R. Tetrahedron Lett. 1996, 37, 1351. (e) South, M. S.; Jakuboski, T. L. Tetrahedron Lett. 1995, 36, 5703. (f) Attanasi, O. A.; Favi, G.; Filippone, P.; Perrulli, F. R.; Santeusanio, S. Org. Lett. 2009, 11, 309. (g) Attanasi, O. A.; Favi, G.; Golobič, A.; Perrulli, F. P.; Stanovnik, B.; Svete, J. Synlett 2007, 2971. (h) Gilchrist, T. L.; Stevens, J. A. J. Chem. Soc., Perkin Trans. 1 1985, 1741.

(18) (a) Lee, C.-H.; Lindsey, J. S. Tetrahedron 1994, 50, 11427. (b) Littler, B. J.; Miller, M. A.; Hung, C.-H.; Wagner, R. W.; O'Shea, D. F.; Boyle, P. D.; Lindsey, J. S. J. Org. Chem. 1999, 64, 1391.

(19) Yoon, S. C.; Cho, J.; Kim, K. J. Chem. Soc., Perkin Trans. 1 1998, 109 .

(20) (a) Butler, R. N.; Coyne, A. G. Chem. Rev. 2010, 110, 6302. (b) Chanda, A.; Fokin, V. V. Chem. Rev. 2009, 109, 725. (c) Simon, M.-O.; Li, C.-J. Chem. Soc. Rev. 2012, 41, 1415. (d) Naravan, S.; Muldoon, J.; Finn, M. G.; Fokin, V. V.; Kolb, H. C.; Sharpless, B. Angew. Chem. Int. Ed. 2005, 44, 3275. (e) Breslow, R. Acc. Chem. Res. 2004, 10, 471.

(21) Attanasi, O. A.; De Crescentini, L.; Filippone, P.; Fringuelli, F.; Mantellini, F.; Matteucci, M.; Piermatti, O.; Pizzo, F. Helv. Chim. Acta 2001, 84, 513.

(22) General Procedure for the Synthesis of Dipyrromethanes Hydrazone $1(0.83 \mathrm{mmol})$ or oxime 4 was added to a solution of $\mathrm{Na}_{2} \mathrm{CO}_{3}(8.30 \mathrm{mmol})$ in $\mathrm{H}_{2} \mathrm{O}(11 \mathrm{~mL})$ and pyrrole $(16.6$ $\mathrm{mmol})$. The reaction mixture was stirred at r.t. for $4 \mathrm{~h}$. After this time the mixture was extracted with $\mathrm{CH}_{2} \mathrm{Cl}_{2}(3 \times 20 \mathrm{~mL})$ and dried over $\mathrm{Na}_{2} \mathrm{SO}_{4}$. After filtration, the solvent and the excess pyrrole were removed under reduced pressure. The product was crystallized with $\mathrm{Et}_{2} \mathrm{O}-n$-hexane, filtered, washed with hexane and dried under vacuum. 
5-(1'-tert-Butoxycarbonylhydrazonoethyl)dipyrromethane (2a)

Yield: $82 \%$; mp $137-138^{\circ} \mathrm{C}\left(\mathrm{Et}_{2} \mathrm{O}-n\right.$-hexane). IR ( $\left.\mathrm{KBr}\right)$ : $v_{\max }=3337,2979,1720,1529,1369,1245,1164,715 \mathrm{~cm}^{-1}$. ${ }^{1} \mathrm{H} \mathrm{NMR}\left(400 \mathrm{MHz}, \mathrm{CDCl}_{3}\right): \delta=8.74$ (br s, $\left.2 \mathrm{H}, \mathrm{NH}\right), 7.51$ (s, $1 \mathrm{H}, \mathrm{NH}$ ), 6.70 (br s, $2 \mathrm{H}, \alpha$-H pyrrolic), 6.13 (br s, $2 \mathrm{H}$, $\beta$-H pyrrolic), 6.05 (br s, $2 \mathrm{H}, \beta-\mathrm{H}$ pyrrolic), 5.05 (s, $1 \mathrm{H}$, meso), 1.83 (s, $3 \mathrm{H}, \mathrm{Me}), 1.53(\mathrm{~s}, 9 \mathrm{H}, t-\mathrm{Bu}) \mathrm{ppm} .{ }^{13} \mathrm{C} \mathrm{NMR}$ $\left(100 \mathrm{MHz}, \mathrm{CDCl}_{3}\right): \delta=156.0,152.9,129.1,117.6,108.3$, 106.9, 81.4, 46.4, 28.3, $13.9 \mathrm{ppm}$. ESI-HRMS: $\mathrm{m} / \mathrm{z}$ calcd for $\mathrm{C}_{16} \mathrm{H}_{23} \mathrm{~N}_{4} \mathrm{O}_{2}[\mathrm{M}+\mathrm{H}]^{+}$: 303.1815; found: 303.1813.
(E)-5-(1'-Hydroxyiminoethyl)dipyrromethane (5a) Yield $74 \%$; mp $142-144{ }^{\circ} \mathrm{C}\left(\mathrm{Et}_{2} \mathrm{O}-n\right.$-hexane). IR (KBr): $v_{\max }$ $=3338,1403,1218,1095,1029,948,728 \mathrm{~cm}^{-1} .{ }^{1} \mathrm{H} \mathrm{NMR}$ $\left(400 \mathrm{MHz}, \mathrm{CDCl}_{3} / \mathrm{DMSO}_{6}\right): \delta=10.02(\mathrm{~s}, 1 \mathrm{H}, \mathrm{OH}), 9.37$ (s, $2 \mathrm{H}, \mathrm{NH}$ ), 6.67 (br s, $2 \mathrm{H}, \alpha-\mathrm{H}$ pyrrolic), 6.06 (br s, $2 \mathrm{H}$, $\beta$-H pyrrolic), 5.97 (br s, $2 \mathrm{H}, \beta-\mathrm{H}$ pyrrolic), 5.00 (s, $1 \mathrm{H}$, meso), 1.84 (s, $9 \mathrm{H}, \mathrm{Me}) \mathrm{ppm} .{ }^{13} \mathrm{C} \mathrm{NMR}\left(100 \mathrm{MHz}, \mathrm{CDCl}_{3} /\right.$ DMSO- $\left.d_{6}\right): \delta=157.0,129.5,117.2,107.6,106.5,44.3,12.3$ ppm. ESI-HRMS: $m / z$ calcd for $\mathrm{C}_{11} \mathrm{H}_{14} \mathrm{~N}_{3} \mathrm{O}[\mathrm{M}+\mathrm{H}]^{+}$: 204.1131; found: 204.1132 . 